Resumen por el autor, Edmond Souchon

Un resumen de la conservación de las disecciones anatómicas con color permanente de los músculos, vasos y órganos.

El autor ha usado durante algún tiempo como solución permanente una solución compuesta de cloruro cálcico y formol, pero nuevos experimentos han demostrado que la sal cálcica no es necesaria. El agente activo es el formol. Una solución de 5 onzas de formol en un galón de agua clara conserva los tejidos e impide el enturbiamiento del líquide. El formol no decolora las disecciones preparadas por los métodos Souchon. La evolución de dichos métodos se basa en los siguientes hechos: Primero, que las disecciones de los músculos sumergidas en una solución de glicerina durante algunos días y después abandonadas al aire libre se oscurecerán mucho al cabo de cierto tiempo. Segundo, que el formol actúa como decolorante de los tejidos coloreados normalmente. Tercero, que las arterias y venas pintadas toleran la acción de cualquier solución ordinaria empleada para la conservación de los tejidos.

Translation by José F. Nonidcz

Cornell, Medical College, New York 


\title{
PRESERVATION OF ANATOMIC DISSECTIONS WITH PERMANENT COLOR OF MUSCLES, VESSELS, AND ORGANS
}

\author{
A SUPPLEMENTARY NOTE \\ EDMOND SOUCHON
}

Tulane School of Medicine, New Orleans, Louisana

The results of the experimental work on the preservation of anatomic dissections have been published in several articles in The Anatomical Record of Philadelphia and elsewhere.

During the evolution of this work it has undergone a number of changes, alterations, substitutions, and additions, etc.

I here publish a supplementary note presenting the final status of the methods.

With regard to the curing method, at the end of three days the preparation is taken out of the glycerin and exposed to the air in a room until the muscles become of a marked brown color. The longer the exposure to the air, the darker the brown. The darker the brown, the darker will be the final color of the muscles in the solution. The shade of the final color can be graded in this way. This curing method has superseded the chemical method.

It is then placed in a permanent solution. For a time I used a solution composed of calcium chloride and formol, but further experimentation has shown that the calcium is not necessary. It is the formol that is the active agent.

A solution of 5 ounces of formol to 1 gallon of clear water will preserve and prevent cloudiness. The formol must be as clear as water. If greenish, it will discolor the solution. If greenish, it should be filtered through bone-black before using to make it clear. Before using the solution, filter it anyhow through boneblack and paper to obtain filtered clearness. 
It may be that 3 ounces of formol may do. Experimentation will determine that. The formol will not bleach the dissections prepared by the Souchon method.

THE EVOLUTION OF THE SOUCHON METHOD FOR THE PRESERVATION OF ANATOMIC DISSECTIONS ${ }^{1}$

I have always been very much interested in the various phases through which discoveries and inventions went before reaching the goal. For this reason I am giving here the various stages of the Souchon methods.

The two methods rest on three facts, none of which is new separately, but is new in the application or combination. They are: First, that dissections of muscles immersed in solution of glycerin for a few days and then removed and left in the open air or enclosed in a receptacle will become very black in coming time. Second, that formol was a bleacher of colored tissues. Third, that painted arteries and veins would stand the action of any ordinary solution used to preserve the tissues. Although I knew all these facts years ago, it took me ten years of work and experiment to bring together the combinations that brought about the results.

When I found out that glycerin would blacken the muscles, I tried several chemicals to reduce the blackness, and it is only after several years of experimentation that I struck formol, which did the work.

I had used many years ago solutions of gelatin to paint pastel drawings before trying a thin coat of damar varnish, but it was only after two or three years of unsuccessful experiments at painting muscles that I bethought myself of first applying a coat of gelatin to the muscles. That gave success.

The elimination of the calcium chloride from the calcium formol solution is due to the fact that $I$ always follow the rule of Pasteur, which consists, when a work is completed, to go over it critically, changing, etc., with a view of simplifying it.

1 At the New Orleans Meeting of the American Medical Association in 1920, the Committee awarded to Dr. Edmond Souchon the Gold Medal for the best scientific exhibit of his anatomic dissections. The dissections were made according to the Souchon methods. 
The only real new discovery was that solutions of 5 per cent formol would not in time bleach the dissections prepared by the Souchon method. They will bleach dissections prepared by other methods. 